\title{
Etablering av Nasjonalt kunnskapssenter om vold og traumatisk stress (NKVTS):
} en satsing for å styrke fagfeltene vold og traumatisk stress

Ved Ellinor Major og Bjørn $\mathrm{H}$ ol

Fra 1. januar 2004 er et nytt nasjonalt kunnskapssenter etablert: Nasjonalt kunnskapssenter om vold og traumatisk stress. Ved å samle organisatorisk flere ressursmiljøer som arbeider med ulike deler av volds- og traumefeltet, samt styrke det med ytterligere ressurser, har Sosial- og helsedirektoratet og fem departementer (Helsedepartementet, Sosialdepartementet, Justisdepartementet, Barne- og familiedepartementet og Forsvarsdepartementet) ønsket å styrke volds- og traumefeltet.

Senteret er etablert som et datterselskap under U N IRA N D A S ved U niversitetet i 0 slo og får lokaler på U llevål universitetssykehus i løpet av sommeren 2004.

N KV TS er etablert av følgende sentre/ ressurser:

\section{- Kompetansesenter for voldsofferarbeid}

- $\mathrm{N}$ asjonalt ressurssenter for seksuelt misbrukte barn

- Psykososialt senter for flyktninger

- R essurser fra K ontor for katastrofepsykiatri etter avtale med Forsvarsdepartementet

N KVT S vil i første omgang bestå av fire seksjoner som dekker følgende temaer:

\section{Stressmestring og kollektive} belastningssituasjoner

2. Flyktninghelse og tvungen migrasjon

3. Vold, familievold og seksuelle overgrep

\section{B arn og ungdom}

I tillegg skal temaene (i hovedsak menn som utøver vold og seksuelle overgrep) som dekkes av de frittstående behandlingstilbudene A Iternativ til Vold (ATV) og Institutt for klinisk sexologi og terapi (IKST ), inkluderes gjennom et samarbeid. Dette gjelder de delene av deres forsknings- og undervisningsvirksomhet som finansieres av staten.

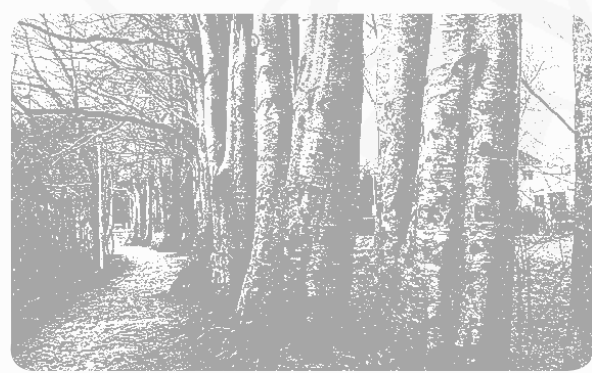

\section{Målsetting}

H ovedmålsettingen med senteret er følgende:

- U tvikle, vedlikeholde og spre kunnskap og kompetanse som kan bidra til å redusere helsemessige og sosiale konsekvenser av vold og traumatisk stress.

- U tvikle, vedlikeholde og spre kunnskap og kompetanse som kan bidra til å forebygge vold og traumatisk stress.

\section{Forutsetninger}

Følgende forutsetninger er lagt til grunn for det nye senteret:

- Senteret skal utvikle kunnskap på et internasjonalt akademisk nivå. Kunnskapen som produseres ved senteret, skal komme praksisfeltet i vid forstand til nytte.

- Senteret skal ikke selv drive klinisk virksomhet, men etablere et kontraktsfestet forhold til relevant praksisfelt.

- Fagpersoner i sentret kan ha delte stillinger mellom senteret, praksisfeltet og universitetet.

Senteret skal ha følgende hovedoppgaver:

\section{- Forskning \\ - U tviklingsarbeid \\ - U ndervisning/kompetanseopp- bygging \\ - Formidling \\ - Veiledning/rådgivning}

Det er en forutsetning at virksomheten skal ha et tverrfaglig perspektiv, og omfatte både biologiske, psykologiske, sosiale, kulturelle og rettslige forhold. Forskningen skal være på høyt vitenskapelig nivå.
Senteret skal legge særlig vekt på brukerperspektivet i sin forskningsvirksomhet. For at virksomheten skal være relevant og ha den kvalitet som er nødvendig vil det være avgjørende med tilgang til praksisfel tet. Senteret skal drive metodeutvikling (praktisk og teoretisk) og virke som premissleverandør for utviklingen av nye tiltak og tverrsektorielt og tverrfaglig samarbeid.

Senteret skal arbeide for at det etableres undervisning innen fagområdet, være premissleverandør for slik undervisning, og bidra til at det utvikles Iæremateriell. Undervisningen skal omfatte grunnutdanning, master- og doktorgradsnivå, samt bidra til systematisk etter- og videreutdanning.

U ndervisningen skal være forsknings- og kunnskapsbasert, og senteret bør inngå samarbeid med utdanningsinstitusjoner, profesjonsorganisasjoner og andre som driver utdanningsvirksomhet.

En viktig oppgave for senteret vil være å samle, bearbeide og formidle kunnskap og informasjon, og à yte veiledning og rådgivning. Senteret skal gi ut vitenskapelige publikasjoner og forskningsrapporter. I tillegg skal senteret tilgjengeliggjøre all den informasjon som er egnet for det og tilrettelegge informasjon for allmennheten og mediene via Intern ett. Senteret skal sikre at nasjonal og internasjonal litteratur blir anskaffet og gjort tilgjengelig.

Det er en utfordring å etablere et nytt senter som kan dra nytte av de ulike miljøers ulikheter og likheter både i tema og arbeidsoppgaver. D et vil være en utfordring både for den direktør som etter hvert vil bli ansatt for å lede senteret, og for de omkring 30 ansatte. Senteret skal evalueres innenfor en treårsperiode.

Ellinor F. M ajor er seniorrådgiver i Sosial- og helsedirektoratet, Avd. for psykisk helse, med vold og traumtisk stress som spesialområde.

B jørn $\mathrm{H}$ ol er styrel eder for $\mathrm{N}$ asjonalt kunnskapssenter om vold og traumatisk stress A S og fakultetsdirektør for Det medisinske fakultet, U niversitetet i 0 slo. 